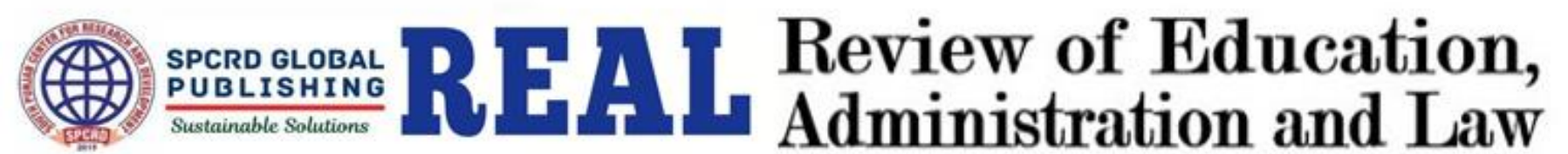 \\ Journal homepage: http://real.spcrd.org ISSN (Print): 2708-1788 ISSN (Online): 2708-3667
}

\section{Stereotyping of Gender Roles and Norms by Society: a Feminist Analysis of I Stand Here Ironing}

\author{
${ }^{a}$ Mujahid Shah, ${ }^{b}$ Marukh Shakir, ${ }^{c}$ Syed Attia \\ a Assistant Professor, Department of English, Abdul Wali Khan University Mardan, Pakistan \\ Email: mujahidshah@awkum.edu.pk \\ ${ }^{\mathrm{b}}$ Assistant Professor, Department of English, Abdul Wali Khan University Mardan, Pakistan \\ ${ }^{\mathrm{c}}$ Department of English, Department of English, Abdul Wali Khan University Mardan, Pakistan
}

\begin{tabular}{l}
\hline ARTICLE DETAILS \\
\hline History: \\
Accepted 22 Aug 2020 \\
Available Online 30 Sep 2020 \\
Keywords: \\
Motherhood, Good/Bad \\
Mothering, Socialization, Gender \\
Roles, Public/social Patriarchy
\end{tabular}

JEL Classification:

M14, M19

DOI: $10.47067 /$ real.v3i2.47

\begin{abstract}
The ideologies rampant in the societies ensure their reproduction through various means. Social institutions are employed to carry out the power structures and uphold the favorable ideologies. These ideologies always favor one over the other by means of differentiation. Gender is one such ideology/construct, which maintains the favorable hegemony of men over women by ascribing different gender roles that justify the society's unequal treatment of men and women. Motherhood is the most natural aspect of female gender. However, society and social institutions are selective of what comprises good or bad mothering. I Stand Here Ironing by Tillie Olsen runs along the same line, where a mother is tormented by guilt of not fulfilling her role as a good mother. This study, thus, offers a critique on social stereotyping of gender roles from a social construction feminist perspective. The study specifically ventures to explore the various factors and institutions that normalize prescribed rules for good and bad mothering. The study also questions the unhelpful stance of the society with respect to child caring services, which makes women accept traditional gender roles. The aim of the study is to gain insight on social manipulation of gender as a way for upholding traditional gender values/roles.
\end{abstract}

(C) 2020 The authors. Published by SPCRD Global Publishing. This is an open access article under the Creative Commons AttributionNonCommercial 4.0

Corresponding author's email address: mujahidshah@awkum.edu.pk

\section{Introduction}

Various ideologies that are rampant in our societies are reproduced and reemphasized through various social institutions. These social institutions usually favour one ideology over the other by means of differentiation. Gender is one such ideology/construct (deBeauvoir, 1974). Social construction 
feminism argues that various social factors, institutions and organizations construct gender and gender roles, which maintains the favorable hegemony of men over women by ascribing differing gender roles, thus, justifying the inequality in treatment of men and women. These social institutions make people believe in the naturalist character of the ascribed gender roles that a gendered being fails to see his/her exploitation at the hands of this social institution of gender.

Social constructionist feminists believe that gender is a social institution itself which determines the norms and accepted attitudes of every single person who inhibits one or the other end of this polarized social institution. No one can go beyond these accepted norms and attitudes without inviting social scorn because of the naturalization of these norms (Lorber, 1997).

The main focus of the social construction feminists is to look at the processes that construct gender differences in implicit and undetectable ways. One of these processes is the gendered division of labor in which women come to inhibit a private sphere "naturally" since, people are made to believe that being a women entails taking care of children, doing the household work etc. Moreover, even as women move towards public spheres there are marred by "gender typing of occupations" (Lorber 1997, p. 30). This gendered typing necessitated only certain type of work 'natural' for men and women. Thus, most people tend to affirm to these social constructs not because it is natural or easy for them but because they come to identify themselves, and their worth in accordance with these socially constructed gendered roles, going against them feels wrong, even to themselves.

Motherhood is considered to be the most natural aspect of the female gender. However, society and the social institutions are selective of what comprises good or bad mothering. A society which believes in "heterosexual social order" (Staples, 1973), lone mothers are seen as an inherently bad and disruptive agents who seek to break the accepted norms entailed by the institution of marriage. These mothers bear the 'naturalized' burden of motherhood and mothering and are made to realize the importance of the institution of marriage for the well-being of their children and themselves.

I stand Here Ironing, by Tillie Olsen runs along the same line where a mother is tormented by an absent entity inquiring about the emotional and physical health of her first child Emily. Emily's mother who is not named once and is known only for her role as a mother is seen being driven by guilt at not fulfilling her socially constructed role of a mother. However, she also implicitly hints at the unhelpful attitude of society.

Looking at the experience of motherhood of Emily's mother, this paper analyzes the experiences of a lone mother with a focus on how the guilty feelings of a mother are based on her sense of gender appropriate behavior for a mother set by society.

\section{Research Objectives}

- To analyse the overwhelming societal expectations of motherhood that makes lone mothers feel guilty for not being good mothers.

- To observe the non-helpful stance of society with respect to child caring services to make women accept the glory of traditional gender roles for women.

\section{Research Questions}

- How internalisation of gendered concepts of marriage and full-time motherhood is depicted in the story I Stand Here Ironing?

- How society sets standards for good mothering without providing social support and places the blame of a child's suffering on a lone (bad) mother? 


\section{Significance of the Study}

Though the phenomenon of a lone (unmarried) mother is not relevant to our society but the analysis of the problems and psychological issues faced by such mothers in the upbringing of the child can enhance our knowledge about the problems of divorced and widowed mothers. Moreover, by investigating the unhelpful stance of society with regard to child caring services, this study aims to gain insights on social manipulation of gender as a way for upholding traditional gender roles.

\section{Delimitation}

The concept of motherhood and mothering has changed a lot over time. However, I have restricted myself to the accounts about motherhood and mothering in the beginning of the $2 \mathrm{O}^{\text {th }}$ for this paper.

\section{Literature Review}

Social constructionist feminists believe that the gender constructs are all reinforced by various social institutions like religion, law and other institution to maintain power and social control by neatly demarcating humans into homogenized labels, outlining their roles and naturalizing them so as to cause no disruption to the maintained and favorable ideologies.

Sexuality, according to Chris Brickell (2006) is a learned social behavior and varies from society to society and from historical context to historical context. The appropriate and tabooed norms changes with societies and other historical changes. There are punitive consequences for those who fail to follow through these socially constructed and contextually varied gendered norms to ensure the "hetero sexual social order" (Lorber 1997, p. 31).

In the same way, the sexuality of women has been socially constructed in relevance to their roles as mothers and wives. Motherhood and mothering are two social constructs which have been made to appear the sole responsibility of women. Silva (1996) argues that this notion of mothering which involves the caring activities is a highly social construct which women are made to affirm to. This social construct of motherhood is homogenized and the individual experiences arising from other socioeconomic factors are discarded when it comes to "calibration of good motherhood" (p. 46).

Carol Smart (1989) also asserts that these rules (for mothering) are standardized and normalized through policies and women are judged on their mothering (feeding, allowing children to sleep in parental bed or in the same room, swaddling etc.) In addition to these physical cares a good mother is portrayed as one who was present for the psychological nurturing of the child as well, who was there to love her children "in a correct fashion" (p. 46) which neither spoiled them or deprived them but which ensured the child's development into an "acceptable citizen". Adherence to these normalized rules of mothering is secured by the stigmas placed on those who challenge them. Moreover, Silva (1996) also talks about the clear distinction made between working and lone mothers and the mothers staying at home. According to her, in a number of societies the former is still seen as disruptive agents in this established gender role. All these calibrations of good mothering are the tests which determine the success or failure of a woman in a society. Silva further argues that mothers from all social classes dutifully followed the prescriptions of mother craft methods, providing both physical and emotional nurturance to their children.

In the $20^{\text {th }}$ century when women entered the workforce as the result of the social conditions caused by the two wars and became extra overburdened not only with housewifery/motherhood but also with employment. The case was worse for the single, unmarried mothers who had little to no social 
benefits for the society was torn whether to treat them as workers or as mothers. According to Schwartz (1983) since the industrialization there has not been a high status for housewives or mothers. Powerful social pressures in the beginning of the $20^{\text {th }}$ century necessitated that women must have children only within marriages. Marriage and motherhood became not only synonymous but also came to be recognized as the best achievements a woman could achieve.

It has been witnessed that full time motherhood was always idealized and its necessity was impressed on the masses. Mothering was portrayed as an aspect of feminine fulfillment and women who didn't find satisfaction in mothering were considered abnormal (Smythe, 2006). Silva (1996) argues that this insistence on the ideology of full-time motherhood was to mask the "social neglect of the needs of women as working mothers" (p. 26), that is, society's own lack of interest in favoring the lone mothers was what caused the persistence of society on the merits of marriage and full time motherhood (Ugarriza, 2002).

All these negative notions and standards of good and bad mothering cannot be discarded for their ideological agendas because according to Butler (1988) gender is an identity achieved by "stylized repetition of acts" (p. 2), that is, people themselves perform certain pre-established acts to construct a socially approved identity. This implies that gender constructs are not only embodied in one's action but they also reproduce the established gender constructs and abide by the historical conventions. Thus, Butler (1988) is right is saying that "to be a woman, one has to become a woman" (p. 2).

Gender, Butler argues is a "project" or "strategy" which has "cultural survival at its end" (p.5). Gender not only humanizes individuals but also those who fail to confirm to gender face backlash from the society. Thus, one can see that it is the social conditions that determine what is the right and wrong behavior for our gender.

I Stand Here Ironing, by Tillie Olsen is a short story which is a part of her short story collection Tell Me a Riddle, published in 1961. Many researchers have talked about the traumatized mother daughter relation unfolded implicitly in the story. Krischner (1976), for example, believes that the story "speaks of love, frustration, rejection and ultimately, acceptance" according to her this story revolves around the classic theme of parent child relation (p. 25).

Similarly, Frye (1981) has talked about the juxtaposition of past and present by the narrator, Emily's mother, as a way of describing her experience of motherhood according to Frye (1981), she uses the present as a standard to gauge her motherhood in the past. According to Frye the story uses the figure of Emily's mother to talk about personal limitations and individual responsibilities. It is a story of mapping out personal guilt and experiences.

Focusing on the character of Emily's mother, this study attempts to analyze the socially constructed and naturalized norm of good and bad mother, which makes women believe in the merit of marriage and do things for which they have no explanation other than them being a socially acceptable gender norm. Moreover, employing the theory of social construction feminist this paper seeks to investigate the lack of social support which causes problems for children of lone mothers.

\section{Research Methodology}

This paper is the qualitative study of Tillie Olsen's short story I Stand Here Ironing. The text is analyzed from social construction feminist perspectives. The ideas about the normalization of mothering and motherhood and the prescribed rules for good mothering discussed by Silva (1996) 
along with ideas Judith Butler's ideas (1988) comprises the theoretical framework for the study.

Moreover, content analysis is used as a tool to explore the themes and concepts already discussed in the paper. Content analysis can be defined as "an interpretive and naturalistic approach that is both observational and narrative in nature and relies less on the experimental elements normally associated with scientific research (reliability, validity and generalizability)" (from Ethnography, Observational Research, and Narrative Inquiry, 1994-2012).

Thus using content analysis, the researcher attempts to analyze the emotional and psychological state of Emily's mother to answer the research questions under the perspectives of social construction feminism.

\section{Analysis and Discussion}

The story, I stand Here Ironing, written by Tillie Olsen is published in 1961. The story is set in the post WWII "world of depression" (Olsen, 1961, p. 1) where the concept of illegitimacy, lone unmarried mothers and their ill-fated children were at rise. At this time the ideology of full-time motherhood, good mothering, marriage were all bombarded on women especially on lone mothers whose freedom from private patriarchy would have meant an end to domination of men. Therefore, even as women tried to structure their lives on their own, public patriarchy in the form of the mounting expectations of mothering along with lack of social support made it look like an impossible feat to do on one's own and made women succumb to believe in acts of marriage and full-time motherhood as natural and the right way (Davin, 1978) which was beneficial for themselves and their children.

As discussed already that motherhood and mothering are social constructs, which are portrayed as the natural duties of women. Those women who fail to follow through the right form of mothering suffer from guilt, because of the fact that people come to gauge their self-worth according to these gender roles. Emily's mother is one such example who is tormented by the reminder of her awful mothering by an invisible authority who asks if she "would manage time to come in" (p.1) and talk with him/her about her daughter. The authority declares that "I'm sure you can help me understand her. She's a youngster who needs help and whom I'm deeply interested in helping" (p.1). This invisible authority and its insistence on Emily' mother being able to help them decipher the problems with Emily shows the society's belief that a mother is responsible for all that a child goes through.

The very opening line of the story "I stand here ironing, and what you asked me moves tormented back and forth with the iron.” (p.1) shows the anguish of this mother at being pricked for something she has been made to believe is her duty. The movement of the iron can be taken as her metaphoric way of easing out the problems she thinks she has caused for her daughter, Emily. Moreover this act of ironing continues throughout the story and we find Emily commenting “Aren't you ever going to finish ironing, Mother?" (p.6) indicates that her incessant indulgence in a prescribed gender role is an effort to psychologically remedy the past diversion from her gender role as a nurturing, full-time, good mother.

As the story moves ahead Emily's mother relates the story of how she had to "leave her (Emily) at daytimes with a woman downstairs" as she "worked or looked for work" (p. 1) this may not seem like a problem now for many mothers work and rely on social support to take care of their children. However, at the time when working (lone, unmarried) mothers weren't seen as adequate mothers and society told them that it was "unnatural" as opposed to their "natural" duty of full time mothering. The society had constructed motherhood as the greatest achievement a woman could 
achieve as Silva (1996) has discussed in her book. According to these standards, Emily's mother lacked when it came to this sole and greatest achievement. She regretfully admits that when she came running back from work Emily would be weeping, "a weeping" she "can hear yet" (p. 2). Therefore her internalized belief in her one sole purpose of life and not being able to fulfill it properly makes her feel horrible and the constant hearing of her daughter's weeping is a proof of the guilt which this internalized belief generated.

In another instance she remembers how a neighbor once told her that she "should smile at Emily more" (p. 2) to which she asks herself, "What was in my face when 1looked at her? I loved her. There were all the acts of love" (p. 2). In her mind going off to work, trying to provide for her through whatever means were available to her was all done out of love for her daughter but she still doubts her own mothering. Her questioning her mothering is relevant to Lorber's (1997) idea that the socially constructed gendered norms are so normalized that people come to judge their identity and worth according to these social ideals and those who don't follow the norms feel like they have done something wrong.

In addition to this her admission at the end of the story that "She (Emily) was a child seldom smiled at. Her father left me before she was a year old. I had to work her first six years when there was work, or I sent her home and to his relatives. There were years she had care she hated ... She was a child of anxious, not proud, love ... I was a young mother; I was a distracted mother... My wisdom came too late" (p. 6-7) shows Emily's mother belief that she failed Emily as a mother and the reason was the lack of father figure in Emily's life, because of the her work and because she was a young mother who wasn't ready to take up the task of mothering. All this is in accordance to what the society had been preaching at that time. According to Joanne Frye (1981) the story uses the figure of Emily's mother to talk about personal limitations and individual responsibilities. It is a story of mapping out personal guilt and experiences.

Lastly, we see her enunciating on her almost religious practice of gender roles just to show that she wasn't a complete loss at the one thing which defined her whole being in the society. She says in the beginning that "I nursed her. They feel that's important nowadays. I nursed all the children, but with her, with all the fierce rigidity of first motherhood, I did like the books then said. Though her cries battered me to trembling and my breasts ached with swollenness, I waited till the clock decreed" (p. 1). She adds after this that she doesn't know why she is giving this information or if it explains anything but keeping in view the expectations the society had from mothers and the normalization of the ideas of what constituted good mothering and what was relegated as bad mothering was drilled so much in the minds of the women that Emily's mother mindless rants can be taken as her providing proof of her good motherhood. At other instances she draws up images of her "ironing, preparing food for the next day or tending the baby" (p. 6). All these musings about not being a good enough mother or her indulgence in the traditional gender roles shows how much she had internalized the idea that the acts of motherhood are what define her as a human being. In addition to this, nowhere in the story does she give a description of herself which is other than that of a mother.

In the previous discussion we saw how she felt guilty for having to leave her with a lady as she went for work. She felt guilty because it was against the prescribed social role but in addition to her guilt she mentions how her "miracle" baby was "no miracle" to the woman downstairs. Moreover, the work for which she had to leave her baby for was because Emily's father had left them because he "could no longer endure sharing with them" (p.1). This implicit explanation could be taken as the scornful view of society which homogenizes all women into one group not taking in their individual 
circumstances. Thus, the passing comment about how the father left them because he didn't want to live with them anymore hints at the ease with which fathers could leave and nobody ever went to him inquiring him for the problems Emily's mother was suffering from.

In addition to what has been discussed above, another accusation which the society makes against the lone mothers is the children don't do well when it comes to studies. Here too in addition to her guilt she gives us a glimpse of the society with its high standards to determine who was a good learner and who was not. We see Emily's mother commenting that "She was not glib or quick in a world where glibness and quickness were easily confused with the ability to learn" (p.4). Therefore, while excepting her lack of quickness she also sarcastically comments on the society, who uses these measures to determine one's learning ability. During this monologue we see Emily's mother talking about her talent for comedy. Later we see Emily being highly praised for her gift of comedy, she was "asked to perform at other schools" (p. 6) and was liked and appreciated by many. This shows that social standards of glibness and quickness don't determine the success of a child since everyone is gifted in their own way and blooms in their own time.

All this guilt of Emily's mother was due to the society's constructed notions of good motherhood, and the ideology that for good mothering a woman needed to stay at home (MacPike, 1989). Much of the pressure which was put on mothers who seek to break this pattern was by pointing towards the lacks the child suffered both physically and mentally as a result of such upbringing. The above analysis shows how Emily's mother was also made to feel responsible for what went on in Emily's life. This is evident from the starting lines where she is asked to come and help understand the problems her daughter has been going through. Emily's mother questions this notion lightly in her monologue in which she says "You think because I am her mother I have a key or that in some way you could use me as a key? She has lived for nineteen years. There is all that life that has happened outside of me, beyond me?” (p. 1). Her questioning of this inherent belief that a mother knows and control all that goes in the life of her child is questioning of the social construct of good mothering.

Thus, we see that Emily's mother rhetorical question and her guilty consciousness points at the society's alertness and eagerness in putting the blame on the mother without looking at the social factors which may have attributed towards the problems a child face over which mother has no control.

\section{Conclusion}

The above analysis explicates that how the gendered norms are bored into the gendered categories so much so that they understand no other way of identifying themselves. This loop of gendered norms with identity creates a dilemma for those who fail to follow the historically outlined and determined possibilities. Motherhood and mothering have always been established as identity markers for women. In $2 \mathrm{O}^{\text {th }}$ century society through various institutions tried to keep women believing in the glory of private patriarchy as a means through which they could carry out these roles without any hindrance. Emily's mother who was a lone mother and who had firm belief in these traditional gender roles depicts her anguish at not fulfilling her mothering duties as she was supposed to do. However, the analysis shows that the things she held herself responsible for were not all her faults, other socio-economic factors also contributed in Emily's mother problems. The society also failed to cater her needs or help her in giving her any kind of moral support. The only concern of the society in this story seems like outlining the rubrics for good mothering and, thus, forming a sense of public patriarchy for women who strived to build an autonomous life for themselves. These social institutions seem to point towards the lacks in the mothering of such mothers thereby deifying the traditional gender roles. 
We can extract from this analysis that the traditional gender norms are not only instilled in the individuals but they are also naturalized by making them relevant to the identities and also by imposing punishments for those who fail to follow them. Since gender is a historical situation which entails naturalized historical possibilities, change can only come if these historical and cultural possibilities calls for acts different from the already established acts. Other such researches can also be conducted to question/analyze the notion of good/bad wife, good/bad daughter which will yield interesting discussions and results.

\section{References}

Brickell, C. (2006). The sociological construction of gender and sexuality. The Sociological Review, 54(1), 87-113.

Butler, J. (1988). Performative acts and gender constitution: An essay in phenomenology and feminist theory. Theatre journal, 4o(4), pp. 519-531.

Davin, A. (1978). Imperialism and motherhood. History Workshop, (5), 9-65. Retrieved September 8, 2019, from http://www.jstor.org/stable/4288158

deBeauvoir. S. (1974). The Second Sex. New York: Vintage

Frye. S. J. (1981). I stand here ironing: Motherhood as experience and metaphor. Studies in Short Fiction, 18(2), pp. 287.92.

Halsey, A.H. (1991, August 12). Time to rebuild the traditional family. Financial Times.

Krischener. L. H. (1976). I Stand Here Ironing. The English Journal. 65(1), pp. 56-59.

Lorber, J. (1997). The variety of feminisms and their contributions to gender equality. Oldenburg: BIS.

MacPike, L. (1989). The new woman, childbearing, and the reconstruction of gender, 1880-1900. NWSA Journal, 1(3), $\quad$ pp. 368-397. Retrieved September 18, 2019, from http://www.jstor.org/stable/4315921

Olsen, T. (1961). Tell me a riddle. London: Virago.

Schwartz. R. C. (1983). More work for mother: The ironies of household technology from the open hearth to the microwave. New York. Basic.

Silva, E. (Ed.). (1996). Good enough mothering?. London: Routledge, https://doi.org/10.4324/9780203434284

Smart. C. (1989). Child custody and the politics of gender. London: Routledge.

Smythe, S. (2006). The good mother: A critical discourse analysis of literacy advice to mothers in the 2oth century (Unpublished doctoral dissertation). University of British Columbia, Vancouver, Canada.

Staples, R. (1973). The black woman in America: Sex, marriage and the family. Chicago:Nelson Hall. Ugarriza, D. N. (2002). Postpartum depressed women's explanation of depression. Journal of Nursing Scholarship. (34) 3, pp. 227-33. 